ZOOLOGIA 30 (3): 266-272, June, 2013

http://dx.doi.org/10.1590/S1984-46702013000300003

\title{
Short-term stability of estuarine benthic assemblages: are storms pattern-defining events?
}

\author{
Orlei A. Negrello Filho ${ }^{1,2} \&$ Paulo C. Lana ${ }^{1}$ \\ ${ }^{1}$ Laboratório de Bentos, Centro de Estudos do Mar, Universidade Federal do Paraná. 83255-000 Pontal do Paraná, PR, \\ Brazil. \\ ${ }^{2}$ Corresponding author. Benthos - Ciência e Tecnologia em Meio Ambiente Ltda. Rua Luiz Antonio Biazzetto 8, \\ 82200-050 Curitiba, PR, Brazil.E-mail: orlei.negrello@gmail.com
}

\begin{abstract}
Storms, associated with strong winds and heavy rains, are often the most severe physical disturbances in shallow coastal areas causing instability to sedimentary environments. We hypothesized herein that if storms influence short-term assemblage structure of macrofauna, then assemblages should change after storms, while remaining relatively stable over calm weather conditions. The study was conducted at the subtropical Paranaguá Bay, in southern Brazil. We selected four $700 \mathrm{~m}^{2}$ sites, at the estuarine outlet, to monitor changes in number of species, number of individuals and Shannon diversity. Sampling was arranged considering the weather forecast so that both before and after conditions could be recorded. Data of each site was tested separately to access the significance of specific (before/ after) comparisons using $t$ tests. There were no clear effects of storms on macrofaunal species richness, abundance and diversity at the four sampled sites. Conversely, we showed that short-term variation in abundances occurred regardless of weather conditions. Increased dispersal may be the most common process associated with storms instead of mortality. Storms that intermittently affect the southern coast of Brazil can be thus seen as minor driving forces of shallowwater estuarine macrofauna. Effects of extreme meteorological events remain to be assessed.
\end{abstract}

KEY WORDS. Benthos; ecosystem disturbance; Paranaguá Bay; sedimentary environments; storms.

Unconsolidated soft sediments, ranging from intertidal shores and estuaries to oceanic abyssal depths, are the most extensive environments on the planet (Murray et al. 2002). Despite their apparent homogeneity, shallow coastal areas are in fact a mosaic of benthic patches where sediment properties and faunal components vary considerably (THrush 1991, HewITT et al. 2008).

Shallow-water surface sediments are constantly under the influence of currents and waves, which cause transport and deposition of particles (KNeBel et al. 1999). On a landscape scale the distribution of patches of sedimentary environments is particularly complex at the outlet of estuaries, due to a combination of geographic and hydrodynamic features (Green et al. 1997, ZAJAC 2008).

Natural physical disturbances may cause destabilization and subsequent mobilization of sediments with direct implications to macrofaunal population dynamics (Probert 1984, Hall 1994). Shallow-water benthic species may be, to a degree, adapted to erosion or deposition (Воск \& Miller 1995), but tolerance to disturbance varies considerably among taxa and recovery to predisturbance conditions may not occur, especially after large scale physical disturbances (UNDERWOOD 1999). Recovery depends upon the active dispersal of adults or upon the transport and redistribution of juveniles and adults in the water column (ARMONIES
1999, Commito 1995, Negrello Filho et al. 2006, Turner et al. 1997) and subsequent resettlement and colonization.

Storms are often presumed to be the most severe physical disturbances in shallow coastal and estuarine environments (Dobbs \& Vozarick 1983, Hall 1994). Ressuspension and transport of sediments and organisms presumably increase under storm conditions (ReEs et al. 1976). The survival rate of ressuspended organisms is uncertain, as either mortality or active/passive dispersal may occur (DERNIE et al. 2003). The role played by such storms in structuring benthic associations in the inner platform shelf and other shallow coastal areas remains to be assessed (Gallucci \& NetTo 2004).

The subtropical southern Brazilian coast has two predominant weather states. The prevalence of eastern-northeastern winds leads to calmer weather, whereas southern-southeastern winds provoke greater swells and storminess with increased bottom sediment disturbance (PARISE et al. 2009). Storms are herein referred to the latter weather condition.

In this study, we hypothesized that if storms influence short-term assemblage structure of macrofauna, then assemblages should change after storms, while remaining relatively stable over periods of calm weather conditions. We carried out shortterm monitoring surveys at four shallow-water sites before and after storms and over equivalent periods of calm weather. 


\section{MATERIAL AND METHODS}

Our study was carried out at the outlet of the estuarine complex of Paranaguá Bay in southern Brazil $\left(25^{\circ} \mathrm{S}, 48^{\circ} \mathrm{W}\right)$. Four sedimentary environments were selected for sampling: two intertidal and two sublittoral (8 $\mathrm{m}$ deep) sites (Fig. 1).

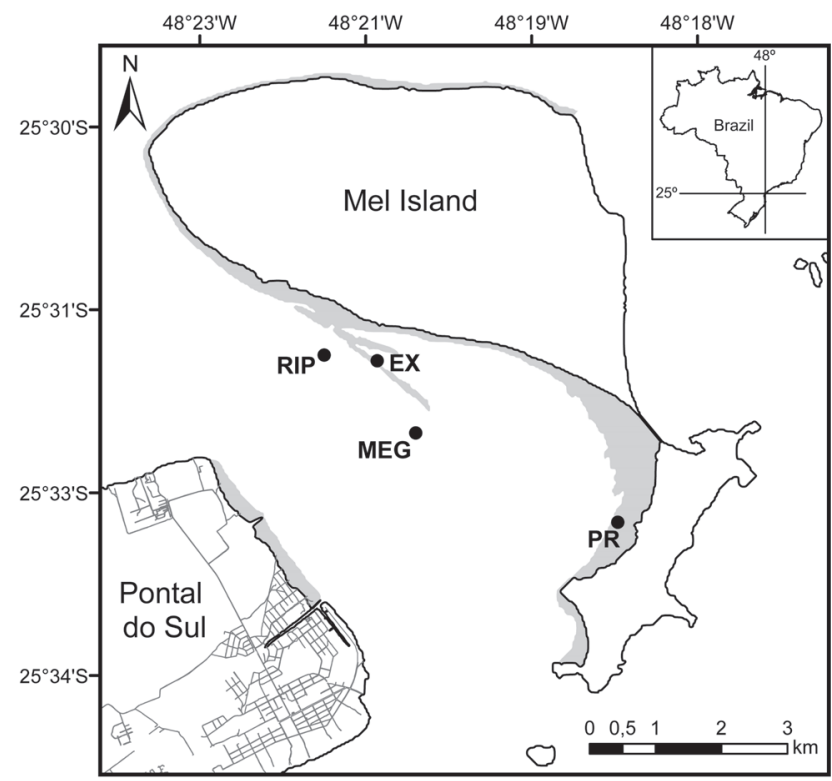

Figure 1. Map of study area showing the location of the different sedimentary environments sampled. (RIP) Rippled sublittoral, (EX) exposed intertidal sand bar, (PR) protected intertidal sand flat, (MEG) sublittoral with conspicuous megafauna.

The sites were classified as exposed sand bar (EX), protected sand flat (PR), rippled sublittoral (RIP) and sublittoral with conspicuous megafauna (MEG). The exposed sand bar, made up mostly by well sorted fine sand, is formed by local current dynamics with occasional disturbance by wave action. The protected sand flat is protected from the southern and southeastern winds by a land mass (Mel Island), and has compacted and moderately sorted sediments, including shells of Anomalocardia brasiliana (Gmelin, 1791), a dominant venerid bivalve on the upper part of the sand flat, and few patches of the seagrass Halodule sp. The rippled sublittoral site is a sand transport environment with megaripples ( $\sim 5 \mathrm{~m}$ long, $\leqslant 40 \mathrm{~cm}$ in height), with mostly well sorted fine sand. The sublittoral megafaunal site is mostly poorly sorted sand, apparently stable with no sign of erosion, with many holothurians and the sanddollar Mellita quinquesperforata (Leske, 1778).

Surveys were conducted at each site from October 2002 to November 2004, over storm and calm (non-storm) conditions, herein considered as statistical treatments. A storm can be understood as a disturbance variable, in the sense that they summon up a series of changes in atmospheric and oceanographic variables (wind speed, pluviosity, wave height, bottom sheer stress, turbidity, salinity). In the study area they can be characterized by wind shifting to a southerly direction, as well as the persistence of southerly winds for at least one day (Rodrigues et al. 2004) (Fig. 2).
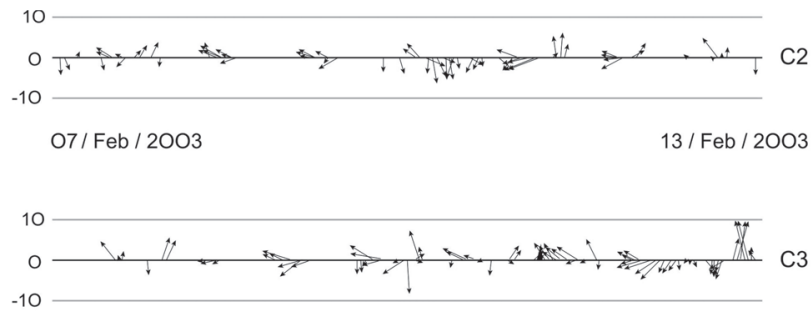

$13 /$ Feb / 2003

$2 \mathrm{O} / \mathrm{Feb} / 2003$

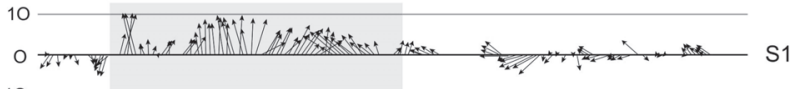
$-10$

$20 /$ Feb / 2003

$26 /$ Feb / 2003

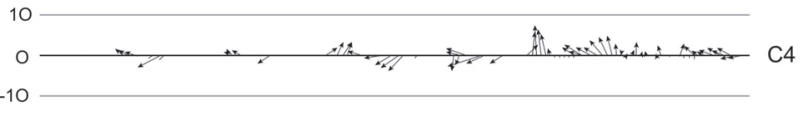

24 / Apr / 2003

29 / Apr / 2003
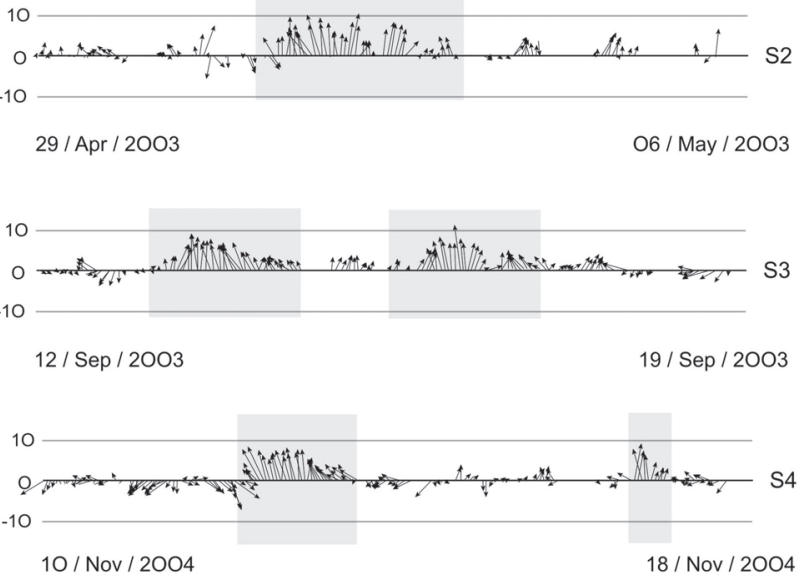

Figure 2.Graph showing wind velocity and directions during periods (5-8 days) between surveys. These periods are considered treatments depending on the presence or absence of wind shifts to a southerly direction (grey area), as well as the persistence of stronger southerly winds for at least one day. S (1-4) represents periods in which storm occurred and C (1-4) controls, or no storm condition. C1 (the only survey that took place in 2002) is not represented because the weather station was operational only by January 2003. 
Storms are not predictable with precision so to choose the best sampling dates, we used weather forecasting available at the National Institute of Spatial Research (Instituto Nacional de Pesquisas Espaciais - INPE/CPTEC, www.cptec.inpe.br). Local atmospheric data were provided by the Physical Oceanography Lab at the Center for Marine Studies, Universidade Federal do Paraná). Once a storm prediction was reliably at hand, we quickly carried out a sampling survey prior to the storm, with subsequent sampling carried out 5-8 days later, as soon as navigation and diving conditions were reestablished (S1-4). Calm conditions were sampled using the same protocol, and over similar time intervals (C1-4).

Samples collected in February 20/Feb/2003 on stations PR and EX were lost due to poor preservation of specimens. In this case only we considered a grater time span for comparisons from 13 to 26/Feb/2003 (S1') and sampled another storm (S4) exclusively on these stations.

Three components of scale are important in ecological studies: grain, lag and extent (HewitT et al. 1997, RafFaelli \& Moller 2000). Thus, at each site sampling by scuba diving was conducted within a $15 \mathrm{~m}$ radius circle (aprox. $700 \mathrm{~m}^{2}$ ) that was positioned with permanent markers so that samples could be taken at exactly the same location. Within this area, 10 random replicates were taken, at each sampling event, at a distance greater than $1 \mathrm{~m}$ from one another to attempt to maintain spatial independence (SKILLeTER 1996). Once sampled, depressions due to taking the sample were seldom visible (and then only at the protected sand flat and the subllitoral megafaunal sites) at a subsequent sampling time.

Since the physical disturbance caused by storms is restricted to the top few sediment surface centimeters (Posey et al. 1996, Gallucci \& NetTo 2004), in which most macrofauna is found, we used a circular corer of $15 \mathrm{~cm}$ wide $\mathrm{x} 5 \mathrm{~cm}$ height to sample. Samples were sieved through a $0.5 \mathrm{~mm}$ mesh and macrofauna were counted and identified under a dissecting microscope to the lowest possible taxonomic level.

We compared species richness, number of individuals and diversity $\left(\mathrm{H}^{\prime}\right)$ separately for each of the four locations, with $t$ tests between consecutive (before/after) sampling dates. Multivariate comparisons of assemblage composition between consecutive dates were carried out using statistical routines in PRIMER version 5.0 (ClaRKE \& WARWick 1994). Bray-Curtis index of similarity was calculated from square root transformed abundance data. An analysis of similarity (ANOSIM) was used to test the prediction that storms are associated with large changes in the macrofauna composition, while there is no or less changes in composition over similar time intervals during calm conditions. Multidimensional scaling (MDS) was used to illustrate changes in assemblage structure over time for each of the four locations.

We focused our attention on how each studied area, individually, responded to passing weather events. Statistical comparisons among sedimentary environments were not pursued because there was no point in testing for differences that were already apparent a priori. Moreover, such comparisons would demand another level of within site replication.

\section{RESULTS}

\section{General community composition at locations}

Macrofauna totaled 11,031 individual organisms in 176 taxa. Locations differed in composition, each with its own, mostly unshared assemblage of species. The protected sand flat (PR) had 61 taxa, the most common of which were the polychaetes Terebellides anguicomus Müller in Grube, 1858, Ninoe sp., Heteromastus sp. and one mollusk, Bulla striata Bruguière, 1792 (mostly juveniles). The exposed sand bar location (EX) had the fewest taxa $(n=20)$, the most common of which were the polychaetes Armandia sp. and Scolelepis sp. The rippled sublittoral location (RIP) had 51 taxa, with Branchiostoma caribaeum Sandevall, 1853, the amphipod Eudevenopus sp. and Armandia sp. being the most common. The sublittoral with megafauna location (MEG) had 97 taxa, dominated by B. caribaeum, Laonice branchiata Nonato, Bolivar \& Lana, 1986 and Magelona papilicornis Müller, 1858.

\section{Before/after comparisons}

Macrofaunal richness, abundance and diversity varied over the duration of the study at all locations (Table I). Both intertidal and subtidal sites showed some significant differences on calm as well as storm treatments. There were significant differences in number of individuals in C4, S2, S3, S4 and diversity in $\mathrm{S} 2$ in the exposed sand bar site (EX). The protected sand flat (PR) showed significant results in number of species (C4 and S2), number of individuals (C1, C2, S1', C4, S2) and diversity $(\mathrm{C} 4, \mathrm{~S} 2)$.

The megarippled site (RIP) showed the most extreme result with no significant variation at all in storm periods. Significant differences were observed in number of species (C2, C3 and C4), number of individuals (C3 and C4) and diversity (C3). The subtidal site with megafauna (MEG) showed significant variations on all parameters during $\mathrm{C} 1$, for diversity in $\mathrm{C} 2$ and number of species in S1.

Most variation was clearly not influenced by storms (Table I). That is, changes in species richness, abundance and diversity in three locations between sampling occasions were more often observed for calm than storm treatments.

Multivariate analysis revealed that community structure did not change as hypothesized, with the results of ANOSIM test indicating that overall differences in structure were similar (if not slightly greater) between sampling occasions during calm periods and after storms (Table II). Significant differences were identified in all temporal comparisons at the protected sand flat and sublittoral with megafauna sites, but $\mathrm{R}$ values were over similar ranges in both treatments, and on average similar (PR: 0.27 for calm v 0.22 for storm) or the same (MEG: 0.31) (Table II). Significant differences in community structure be- 
Table I. Results of $\mathrm{t}$ tests between sampling occasions for calm (C1-4) and storm (S1-4) treatments for all four sedimentary environments. Values are shown in bold when $p$ is significant $(p<0.05)$. Samples collected in 20/Feb/2003 on stations PR and EX were lost due to poor preservation of specimens. In this case only we considered a grater time span for comparisons from 13 to 26/Feb/2003 (S1').

\begin{tabular}{|c|c|c|c|c|c|c|c|c|c|c|c|c|}
\hline & \multicolumn{6}{|c|}{ Exposed sand bar } & \multicolumn{6}{|c|}{ Protected sand flat } \\
\hline & \multicolumn{2}{|c|}{$S$} & \multicolumn{2}{|c|}{$\mathrm{N}$} & \multicolumn{2}{|c|}{$\mathrm{H}^{\prime}$} & \multicolumn{2}{|c|}{$S$} & \multicolumn{2}{|c|}{$\mathrm{N}$} & \multicolumn{2}{|c|}{$\mathrm{H}^{\prime}$} \\
\hline & $\mathrm{t}$ & $\mathrm{p}$ & $\mathrm{t}$ & $\mathrm{p}$ & $\mathrm{t}$ & $\mathrm{p}$ & $\mathrm{t}$ & $\mathrm{p}$ & $\mathrm{t}$ & $p$ & $\mathrm{t}$ & $P$ \\
\hline $\mathrm{C} 1$ & -2.057 & 0.064 & 0.974 & 0,351 & 0.936 & 0.363 & -1.902 & 0.073 & -2.807 & 0.012 & -0.798 & 0.435 \\
\hline $\mathrm{C} 2$ & 1.659 & 0.115 & 0.891 & 0,384 & 0.738 & 0.470 & -1.745 & 0.100 & -2.137 & 0.048 & -0.934 & 0.364 \\
\hline $\mathrm{C} 4$ & -0.553 & 0.587 & -2.239 & 0,038 & 0.814 & 0.426 & 2.382 & 0.028 & 2.397 & 0.028 & 2.312 & 0.033 \\
\hline$S 1^{\prime}$ & 0.192 & 0.850 & 0.992 & 0,335 & 0.374 & 0.712 & 1.007 & 0.327 & 2.350 & 0.030 & 0.036 & 0.972 \\
\hline $\mathrm{S} 2$ & 0.198 & 0.845 & 2.118 & 0,048 & -2.497 & 0.022 & -2.984 & 0.008 & -2.252 & 0.037 & -2.639 & 0.017 \\
\hline S3 & 1.138 & 0.270 & 3.084 & 0,006 & -0.609 & 0.550 & -0.490 & 0.630 & 0.911 & 0.375 & -0.350 & 0.730 \\
\hline \multirow[t]{4}{*}{ S4 } & 1.949 & 0.067 & 4.316 & 0,000 & -1.953 & 0.067 & -0.297 & 0.770 & -0.576 & 0.572 & -0.199 & 0.845 \\
\hline & \multicolumn{6}{|c|}{ Rippled sublittoral } & \multicolumn{6}{|c|}{ Sublittoral with conspicuous megafauna } \\
\hline & \multicolumn{2}{|c|}{$S$} & \multicolumn{2}{|c|}{$\mathrm{N}$} & \multicolumn{2}{|c|}{$\mathrm{H}^{\prime}$} & \multicolumn{2}{|c|}{$\mathrm{S}$} & \multicolumn{2}{|c|}{$\mathrm{N}$} & \multicolumn{2}{|c|}{$\mathrm{H}^{\prime}$} \\
\hline & $\mathrm{t}$ & $\mathrm{p}$ & $\mathrm{t}$ & $\mathrm{p}$ & $\mathrm{t}$ & $\mathrm{p}$ & $\mathrm{t}$ & $\mathrm{p}$ & $\mathrm{t}$ & $\mathrm{p}$ & $\mathrm{t}$ & $P$ \\
\hline $\mathrm{C} 1$ & 1.584 & 0.134 & -1.733 & 0.104 & 1.982 & 0.066 & -2.830 & 0.014 & 2.919 & 0.012 & -6.089 & 0.000 \\
\hline $\mathrm{C} 2$ & -2.902 & 0.010 & -1.579 & 0.132 & -1.410 & 0.175 & -2.106 & 0.049 & -0.039 & 0.969 & -3.663 & 0.002 \\
\hline$C 3$ & 4.309 & 0.000 & 2.957 & 0.009 & 2.486 & 0.024 & 1.861 & 0.079 & 1.126 & 0.275 & 2.092 & 0.051 \\
\hline $\mathrm{C} 4$ & -2.744 & 0.013 & -3.267 & 0.004 & -0.814 & 0.427 & 1.052 & 0.308 & 1.155 & 0.265 & -0.115 & 0.910 \\
\hline $\mathrm{S} 1$ & -0.658 & 0.519 & -0.895 & 0.383 & -0.047 & 0.963 & -1.988 & 0.062 & -2.238 & 0.038 & -1.112 & 0.281 \\
\hline $\mathrm{S} 2$ & 0.726 & 0.477 & 1.782 & 0.092 & -0.315 & 0.757 & 0.179 & 0.860 & -0.901 & 0.380 & 1.603 & 0.127 \\
\hline S3 & -0.779 & 0.447 & -0.743 & 0.468 & -0.563 & 0.580 & 0.122 & 0.904 & 1.771 & 0.097 & -0.558 & 0.585 \\
\hline
\end{tabular}

Table II. Results of ANOSIM pair-wise comparisons of assemblage similarity between sampling occasions for calm (C1-4) and storm (S1-4) treatments for all four sedimentary environments $(P R=$ protected sand flat, $E X=$ exposed sand bar, RIP $=$ rippled sublittoral, $M E G=$ sublittoral with conspicuous megafauna). $R$ values are shown in bold when $p$ is significant $(p<0.05)$. Samples collected in $20 /$ Feb/2003 on stations PR and EX were lost due to poor preservation of specimens. In this case only we considered a grater time span for comparisons from 13 to 26/Feb/2003 (S1').

\begin{tabular}{|c|c|c|c|c|c|}
\hline & & PR & EX & RIP & MEG \\
\hline $\mathrm{C} 1$ & 03/Oct/2002-08/Oct/2002 & 0.373 & 0.690 & -0.039 & 0.431 \\
\hline $\mathrm{C} 2$ & 07/Feb/2003-13/Feb/2003 & 0.318 & 0.140 & 0.111 & 0.485 \\
\hline $\mathrm{C} 3$ & 13/Feb/2003-20/Feb/2003 & - & - & 0.063 & 0.137 \\
\hline $\mathrm{C} 4$ & 24/Apr/2003-29/Apr/2003 & 0.132 & -0.008 & 0.330 & 0.171 \\
\hline $\mathrm{S} 1$ & 20/Feb/2003-26/Feb/2003 & - & - & 0.049 & 0.128 \\
\hline$S 1^{\prime}$ & 13/Feb/2003-26/Feb/2003 & 0.288 & 0.041 & - & - \\
\hline S2 & 29/Apr/2003-06/May/2003 & 0.183 & 0.000 & 0.158 & 0.551 \\
\hline S3 & 12/Sep/2003-19/Sep/2003 & 0.199 & 0.084 & 0.123 & 0.241 \\
\hline S4 & $10 /$ Nov/2004-18/Nov/2004 & 0.211 & 0.404 & - & - \\
\hline
\end{tabular}

tween treatments were found less frequently on exposed sand bar and rippled sublittoral, and on average R values were small, similar between treatments and the observed changes seemingly unrelated to storms.

The MDS ordination plots (Fig. 3) illustrate that ANOSIM results, showing that the magnitude of change in community structure between sampling occasions is similar for both calm and storm treatments for all sites. The MDS plots also show that there was no general pattern of grouping of samples by treatment or any general tendency for the post storm samples to illustrate any recovery towards the community structure observed during calm periods. 

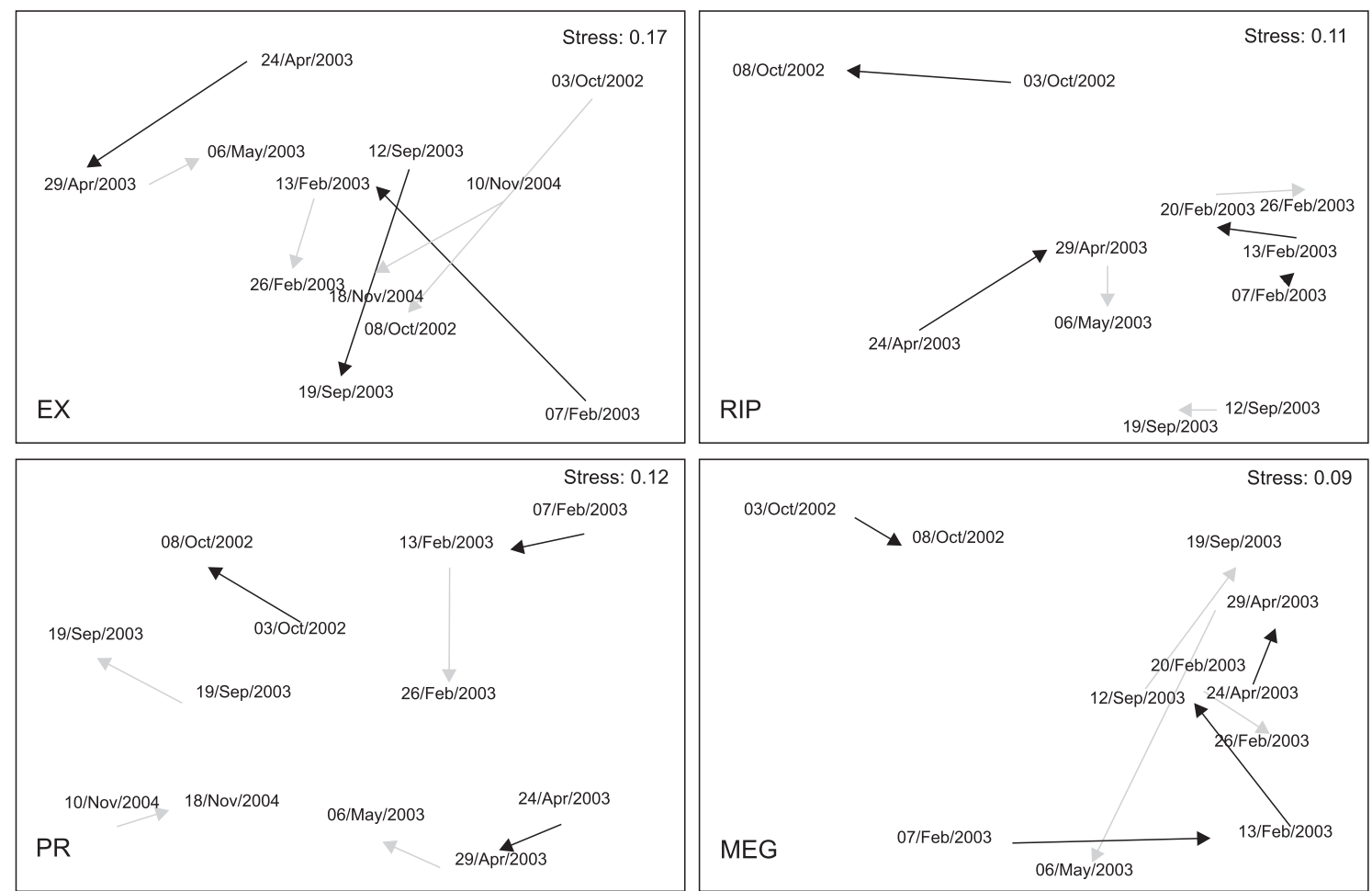

Figure 3. Non-metric multidimensional scaling plots of sampling dates at the four locations: exposed sand bar (EX), protected sand flat (PR), rippled sublittoral (RIP) and sublittoral with conspicuous megafauna (MEG). Dates represent the centroids of ten sampling units. Arrowed lines connect consecutive dates for storm (light grey lines) and calm (solid lines) treatments.

\section{DISCUSSION}

Our study tested for the presumed effect of storms on macrofaunal assemblages at four sites of Paranaguá Estuarine Complex. These events are the most common, and sometimes most intense, natural disturbance along the southern Brazilian coast, hence their potential to regulate macrobenthic dynamics (Rodrigues et al. 2004, PARISE et al. 2009). For this reason, we expected to get results with a consistent pattern of changing numbers of species and individuals after such events and relative stability during calm weather periods.

Actual results refuted this working hypothesis. There were no clear short-term (5-8 days) effects of storms on the species richness, abundance and diversity of estuarine macrofauna. Results showed that fluctuation in numbers is the norm, but there were no temporal recurring pattern after storms (S1, S2, S3 and S4) in each site. Conversely, spatial differences were equally variable, with changes occurring regardless of weather conditions.

The variable temporal response in all measured assemblage parameters at all four sites, both during calm and storm conditions can be interpreted as a constant rearrangement of macrofaunal community structure. Multivariate analyses showed that time periods before and after storms had no tendency to form groups (pre-disturbance vs. post-disturbance). What seems to be the case in all four studied sites is an ongoing modification in species composition and number of individuals.

Changes can occur as animals arrive or leave a site, either by dispersal or mortality. Instead of the negative effects of increased mortality associated with disturbance events, increased dispersal may be the most common process at the study sites as suggested by the significant differences more often observed in the number of individuals than in number of species (Palmer et al. 1996). Fluctuating numbers of individuals and an uneven pattern of change in the number of species suggested that dispersal and new colonization could account for observed changes in the composition and abundance of local assemblages (GÜNTHER 1992).

It can be argued that the time lag between sampling occasions (which was determined mainly by logistical constraints) may have been too long to detect a short term effect of the storms on the macrofauna assemblages at the study sites. Storm events typically lasted 48 hours at most (Fig. 2), and it is possible that any significant changes in assemblage structure may have only been detectable shortly after, and that recovery had 
already begun by the time samples were taken 5-8 days after the storm. Working at a sandy beach, where sampling during storms was viable, GALLUCCI \& NeTTO (2004) reported a decrease in numbers of species, abundance and diversity, that lasted for the day of the disturbance only, with fast recovery to previous conditions soon after.

The question of scale is the key to sum up our current findings, or at least to put them into context, even in the absence of better long-term meteorological information. The fact that ecological descriptors showed no clear variation patterns and oscillated in an uneven way, mostly during calm periods, refuted our initial hypotheses that storms cause decreases in the number of species and individuals. Even on mobile sands, both at intertidal and subtidal areas, recurring and consistent changing patterns were not observed.

We were able to show that "regular" subtropical storms are not major driving forces of the composition and abundance of shallow-water estuarine macrofauna in different sedimentary estuarine environments. However, we do not discard the possibility that extreme meteorological events over the Western South Atlantic Ocean, such as the Catarina subtropical hurricane (MCTAGGART-CoWAN et al. 2004), may be proven relevant to affect benthic assemblages (DAvis et al. 2004). Moreover, factors such as the role of cyclical oscillations such as tidal currents and flooding (GRILo et al. 2011) must be taken into account.

\section{ACKNOWLEDGMENTS}

We thank CAPES (Cordenação de Aperfeiçoamento de Pessoal de Nível Superior) for the financial support to O.A. Negrello Filho. We thank our colleagues from the Zoology Department and the Center for Marine Studies of the Universidade Federal do Paraná, Brasil, for their support throughout the study. James J. Roper revised a first English version and provided helpful suggestions to improve the manuscript. Mauricio Noernberg provided useful references. Commentaries of Ashley Rowden, Sionei R. Bonatto and two anonymous reviewers helped to clarify ideas and overall structure of the paper. O.A. Negrello Filho wishes to pay homage to William Sealy Gosset (for the invention of Student's $t$ ).

\section{LITERATURE CITED}

Armonies, W. 1999. Drifting benthos and long-term research: why community monitoring must cover a wide spatial scale. Seckenbergiana Maritima 29: 13-18.

Bock, M.J. \& D.C. MilLer. 1995. Storm effects on particulate food resources on an intertidal sandflat. Journal of Experimental Marine Biology and Ecology 187: 81-101.

Clarke, K.R. \& R.W. Warwick. 1994. Change in marine communities: an approach to statistical analysis and interpretation. Plymouth Marine Laboratory, 859p.
Commito, J.A.; S.F. Thrush; R.D. Pridmore; J.E. Hewitt \& V.J. Cummings. 1995. Dispersal dynamics in a wind-driven benthic system. Limnology and Oceanography 40: 15131518.

Davis, S.E.; J.E. Cable; D.L. Childers; C. Coronado-Molina; J.W. Day; C.D. Hittle; C.J. Madden; E. Reyes; D. Rudnick \& F. Sklar. 2004. Importance of episodic storm events in controlling ecosystem structure and function in a Gulf Coast Estuary. Journal of Coastal Research 20: 1198-1208.

Dernie, K.M.; M.J. Kaiser; E.A. Richardson \& R.M. WarWick. 2003. Recovery of soft sediment communities following physical disturbance. Journal of Experimental Marine Biology and Ecology 285-286: 415-434.

Dobbs, F.C. \& J.M. Vozarick. 1983. Immediate effects of a storm on coastal infauna. Marine Ecology Progress Series 11: 273-279.

GallucCI, F. \& S.A. NetTo. 2004. Effects of the passage of cold fronts over a coastal site: an ecosystem approach. Marine Ecology Progress Series 281: 79-92.

Green, M.O.; K.P. Black \& C.L. Amos. 1997. Control of estuarine sediment dynamics by interactions between currents and waves at several scales. Marine Geology 144: 97-116.

Grilo, T.F.; P.G. Cardoso; M. Dolbeth; M.D. Bordalo \& M.A. ParDAL. 2011. Effects of extreme climate events on the macrobenthic communities' structure and functioning of a temperate estuary. Marine Pollution Bulletin 62: 303-311.

GÜNTHER, C. 1992. Dispersal of intertidal invertebrates: a strategy to react to disturbances of different scales? Netherlands Journal of Sea Research 30: 45-56.

HaLL, S.J. 1994. Physical disturbance and marine benthic communities: life in unconsolidated sediments. Oceanography and Marine Biology: an Annual Review 32: 179-239.

Hewitt, J.E.; R.D. Pridmore; S.F. Thrush \& V.J. Cummings. 1997. Assessing the short-term stability of spatial patterns of macrobenthos in a dynamic estuarine system. Limnology and Oceanography 42 (2): 282-288.

HewitT, J.E.; S.F. Thrush \& P.D. DAYTon. 2008. Habitat variation, species diversity and ecological functioning in a marine system. Journal of Experimental Marine Biology and Ecology 366: 116-122.

Knebel, H.J; R.P. Signell; R.R. Rendigs; L.J. Poppe \& J.H. List. 1999. Sea floor environments in the Long Island Sound estuarine system. Marine Geology 155: 277-318.

McTaggart-Cowan, R.; L.F. Bosart; C.A. Davis; E.H. Atallah; J.R. Gyakum \& K.E. EMAnUel. 2006. Analysis of Hurricane Catarina (2004). Monthly Weather Review 134: 3029-3053.

Murray, J.M.H.; A. Meadows \& P.S. Meadows. 2002. Biogeomorphological implications of microscale interactions between sediment geotechnics and marine benthos: a review. Geomorphology 47: 15-30.

Negrello Filho, O.A.; A.J. Underwood \& G.M. Chapman. 2006. Recolonization of infauna on a tidal flat: an experimental analysis of modes of dispersal. Journal of Experimental Marine Biology and Ecology 328: 240-250. 
Palmer, M.A.; J.D. Allan \& C.A. Butman. 1996. Dispersal as a regional process affecting the local dynamics of marine and stream benthic invertebrates. Trends in Ecology and Evolution 11 (8): 322-326.

Parise, C.K.; L.J. Calliari \& N. Krusche. 2009. Extreme storm surges in the south of Brazil: atmospheric conditions and shore erosion. Brazilian Journal of Oceanography 57: 175-188.

Posey, M.; W. Lindberg; T. Alphin \& F. Vose. 1996. Influence of storm disturbance on an offshore benthic community. Bulletin of Marine Science 59: 523-529.

ProberT, P.K. 1984. Disturbance, sediment stability, and trophic structure of soft bottom communities. Journal of Marine Research 42: 893-921.

Raffaelli, D. \& H. Moller. 2000. Manipulative field experiments in animal ecology: Do they promise more than they can deliver? Advances in Ecological Research 30: 300-338.

Rees, E.I.S.; A. Nicholaidou \& P. Laskaridou. 1976. The effects of storms on the dynamics of shallow water benthic associations, p. 465-474. In: B.F. Keegan; P. Òcèidigh \& P.J.S. Boaden (Eds). Biology of Benthic Organisms. New York, Pergamon.
Rodrigues, M.L.G.; D. Franco \& S. Sugahara. 2004. Climatologia de frentes frias no litoral de Santa Catarina. Revista Brasileira de Geofísica 22 (2): 135-151.

Skilleter, G.A. 1996. An experimental test of artifacts from repeated sampling in soft sediments. Journal of Experimental Marine Biology and Ecology 205: 137-148.

Thrush, S.F. 1991. Spatial pattern in soft-bottom communities. Trends in Ecology and Evolution 6 (3): 75-79.

Turner, S.J.; J. Grant; R.D. Pridmore; J.E. HewitT; M.R. Wilkinson; T.M. Hume \& D.J. Morrisey. 1997. Bedload and water-column transport and colonization process by post-settlement macrofauna: Does infaunal density matter? Journal of Experimental Marine Biology and Ecology 216: 51-75.

UnDERWOOD, A.J. 1999. Physical disturbances and their direct effect on an indirect effect: responses of an intertidal assemblage to a severe storm. Journal of Experimental Marine Biology and Ecology 232: 125-140.

ZAJAC, R.N. 2008. Macrobenthic biodiversity and seafloor landscape structure. Journal of Experimental Marine Biology and Ecology 366: 198-203.

Submitted: 11.XII.2012; Accepted: 02.IV.2013.

Editorial responsibility: Rosana M. da Rocha 